\title{
Cooking-Pit Sites as Assembly Sites: Lunde in Vestfold, South-East Norway_A Regional Assembly Site in the Early Iron Age?
}

\author{
MARIE ØDEGAARD*
}

\begin{abstract}
Introduction
Since the EARLy 2000s, SEVERAl large-scale cooking-pit sites have been uncovered in Norway and interpreted as traces of large gatherings. Similar cooking-pits are increasingly found by development-led excavations across northern Europe. Cooking-pits are earth ovens for dry-cooking. A pit is dug, filled with stones which are heated, and when the pit is sealed by a layer of turf, it will function like an oven for cooking meat or fish. There are two types of sites: 'cooking pit lines', and 'unstructured sites'. 'The focus of this chapter is on the latter, which are often referred to as 'specialised cooking-pit sites' as they are characterised by large numbers of pits unrelated to contemporary settlement and mainly dated to the Roman Iron Age and the Migration period, that is, AD $0-600 .^{2}$ Their functions are debated. ${ }^{3}$ Some see them as traces of cult sites. Sometimes these sites

\footnotetext{
* I would like to thank Professor Ingvild Øye, Professor Frode Iversen and Eleanor Rye for valuable comments on this chapter.

${ }^{1}$ M. B. Henriksen 'Danske kogegruber og kogegrubefelter fra yngre bronzealder og ældre jernalder', in L. Gustafson, T. Heibreen and J. Martens (eds), De gåtefulle kokegroper, Varia, 58 (Oslo, Kulturhistorisk Museum, 2005), pp. 77-102 at 98; M. Løvschal and D. Fontijn, 'Directionality and axiality in the Bronze Age: Cross-regional landscape perspectives on 'fire pit lines' and other pitted connections', World Archaeology 2018, 1-17 https://doi.org/10.1080/00438243.2018.1488609

2 L. Gustafsen, 'Om kokegroper i Norge', in Gustafson, Heibreen and Martens (eds), De gåtefulle kokegroper, pp. 103-8 at p. 105; M. B. Henriksen, 'Bål i lange baner - om brugen af kogegruber i yngre bronzealder og ældre jernalder', Fynske Minder (1999), 93-123 at 96; J. Martens, 'Kogegruber i syd og nord - samme sag?', in Gustafson, Heibreen and Martens (eds), De gåtefulle kokegroper, pp. $37-56$ at p. 37.

3 O. Farbregd, 'Kolgroper og keltartidsproblem', Viking, 36 (1972), 144-67; O. Farbregd, 'Kolgropertalrike og vikige, men problematiske minne frå vår eldste jernalder', in R. Nydal, S. Westin, U. Hafsten and S. Gulliksen (eds), Fortiden i søkelyset. 14C-datering gjennom 25 år (Trondheim,
} 
coincide with assembly places known from a later period and/or with later medieval churches in Eastern Norway, ${ }^{4}$ and it has been suggested that they had legal functions as judicial assemblies or early thing-sites. ${ }^{5}$ The known institution for justice in Scandinavia in the period after AD 800 was the thing (Old Norse (ON) ping), a 'multi-functional site for discussion and determination of any matter of communal concern' ${ }^{6}$ Dating of the cooking-pit sites indicates that they went out of use long before law areas were evidenced in Norway. However, no attempt has been made to study these sites in their wider geographical, legal and social context; this is the aim of this chapter.

To discuss this, the Viken area will be studied; Viken is the medieval name for the Oslo Fjord region in south-east Norway and Bohuslän in present-day Sweden. The area corresponds to the medieval provincial law area of Borgarthing (Figure 5.1). According to the sagas, King Olaf II Haraldsson established the town of Borg in 1016 and allegedly founded a law-thing there, the Borgarthing. ${ }^{7}$ Previous discussion has focused on whether there was a legal community and a single regional law-thing in Viken before this ${ }^{8}$ and if some of the large cooking-pit sites functioned as early thing-sites in this area. ${ }^{9}$

The focus of this chapter is a case-study of one medieval administrative area, the so-called skipreiða of Numedal, in the county of modern-day Vestfold. The ON term skipreiður (sg. skipreiða) denoted coastal districts connected with naval defence at an early stage of the Norwegian kingdom in the 10th and 11th centuries; however, the skipreiður also functioned as judicial districts, represented by

Laboratoriet for radiologisk datering, 1979), pp. 131-7; L.-E. Gjerpe, 'Kult, politikk, fyll, vold og kokegropfeltet på Hov', Primitive tider, 4 (2001), 5-17; L.-E. Narmo, 'Kokekameratene på Leikvin. Kult og kokegroper', Viking, 59 (1996), 79-100.

${ }^{4}$ L.-E. Gjerpe (ed.), Kulturhistoriske, metodiske og administrative erfaringer. E18-prosjektet Vestfold 4, Varia, 74 (Oslo, Kulturhistorisk Museum, 2008), pp. 56-7; Narmo, 'Kokekameratene på Leikvin’; K. Oma, 'Fasanhagen, Lystad 128/5, Sandefjord kommune, Vestfold' (unpublished excavation report, University of Oslo, Museum of Cultural History Archive, 2001); G. Reitan, 'Fra kokegroper til halshogging på Faret—bruk og gjenbruk av kultsted gjennom 1600 år', in Gustafson et al. (eds), De gåtefulle kokegroper, pp. 177-88; D. Skre (ed.), Kaupang in Skiringssal, Norske Oldfunn 22, Kaupang Excavation Project, 22, vol. 1 (Århus, Aarhus University Press, 2007), pp. 385-406; K. Stene, 'Kokegropene på Våle prestegård — klassisk beliggenhet for et kokegropfelt?' in Gustafson et al. (eds), De gåtefulle kokegroper, pp. 167-76.

${ }^{5}$ Gjerpe, Kulturhistoriske, metodiske og administrative erfaringer, pp. 56-7; Skre, Kaupang in Skiringssal, pp. 385-406; M. Ødegaard, 'Tingsted og territorium. Organisering av rettslandskapet i Viken i jernalder og middelalder' (PhD thesis, Bergen, 2015), p. 420; M. Ødegaard, 'Assembling in Times of Transitions - the Case of Cooking-Pit Sites', in B. Niell and C. Theune (eds), Transitions and Transformations in the Medieval and Early Modern Countryside, Ruralia XII (Leiden, Sidestone Press, in press). Assemblies were termed ping in medieval sources in Scandinavia and Iceland.

${ }^{6} \mathrm{H}$. Vogt and K. Esmark, introduction to part two, in K. Esmark, L. Hermanson, H. J. Orning and H. Vogt (eds), Disputing Strategies in Medieval Scandinavia, Medieval Law and Its Practice, 16 (Leiden, Brill, 2013), pp. 141-60, at 152.

7 Heimskringla, ed. and trans. B. Aðalbjarnarson, 3 vols, Íslenzk fornrit, 26-8 (Reykjavík, Hið íslenzka fornritafélag, 1941-51), vol. 2, The Separate Saga of St Olaf, ch. 61.

${ }^{8}$ E. Hertzberg, Grundtrcekkene i den celdste norske proces (Kristiania, A. W. Brøgger, 1874), pp. 1436; F.-A. Stylegar and P. Norseng, 'Del 2', in E. A. Pedersen, F. A. Stylegar and P. G. Norseng (eds), Øst For Folden. Østfolds Historie, 1 (Sarpsborg, Østfold Fylkeskommune, 2003), pp. 279-512 at 506-7. ${ }_{9}^{9}$ Gjerpe, Kulturhistoriske, metodiske og administrative erfaringer, pp. 56-7; Skre, Kaupang in Skiringssal, pp. 385-406; Ødegaard 'Tingsted og territorium', pp. 301-17. 


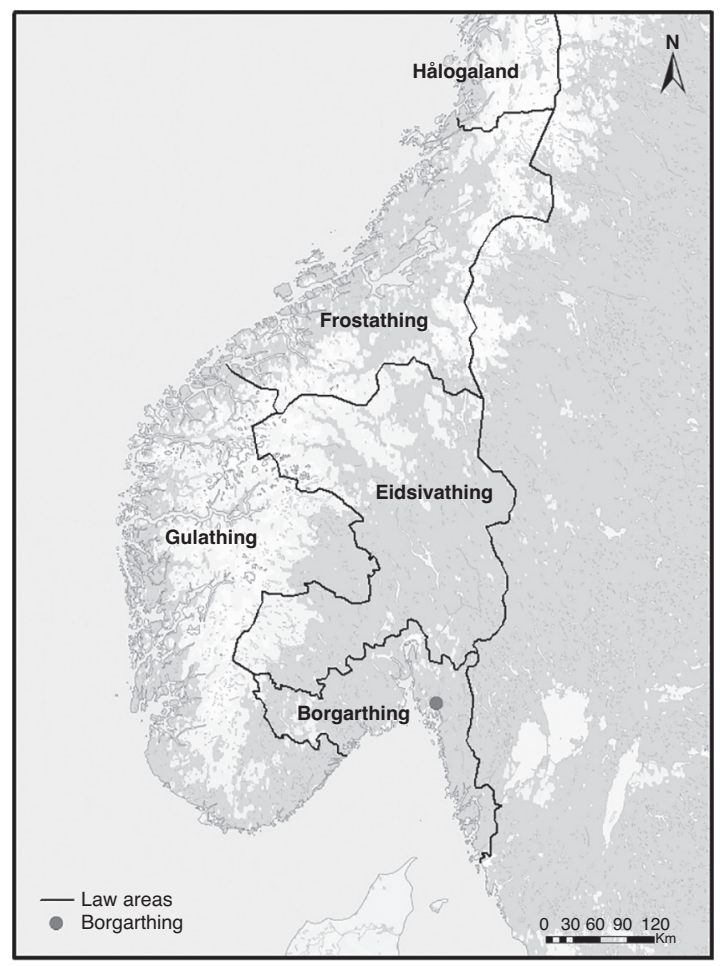

Figure 5.1 The investigation area with the location of the law-thing at Borg (Marie Ødegaard)

their respective thing-sites. ${ }^{10}$ Three large cooking-pit sites are known from the Numedal area, at the farms of Lunde, Lystad and Bommestad (Figure 5.2); here the focus is predominantly on the site at Lunde. The sites will be compared with other assembly sites and administrative areas from the period between the early Iron Age and the end of the medieval period AD 1-1600, in order to discuss the thing system and the area's geopolitical and social context over time. The central questions addressed below are these: 1 ) what are the characteristics of cooking-pit sites? 2) do they represent local or regional levels of social organisation? 3) if the cooking-pit sites are early thing-sites, what can that tell us about the formation and development of the law province in Viken in the Iron Age?

\section{Method and Sources}

Few thing-sites are known from Norway, which makes their archaeological and topographical characterisation uncertain. Later written sources dating from the 14 th to 17 th centuries, including sagas, can play a role in the identification of

${ }^{10}$ H. Bjørkvik 'Skipreide', in Kulturhistorisk Leksikon for Nordisk Middelalder. Fra vikingtid til reformasjonstid, 15 (Copenhagen, Rosenkilde og Bagger, 1982), pp. 546-51; P. S. Andersen, 'Ting', in Kulturhistorisk Leksikon for Nordisk Middelalder, fra vikingtid til reformasjonstid, 18 (Copenhagen, Rosenkilde og Bagger, 1974), pp. 346-59 at 348-9. 


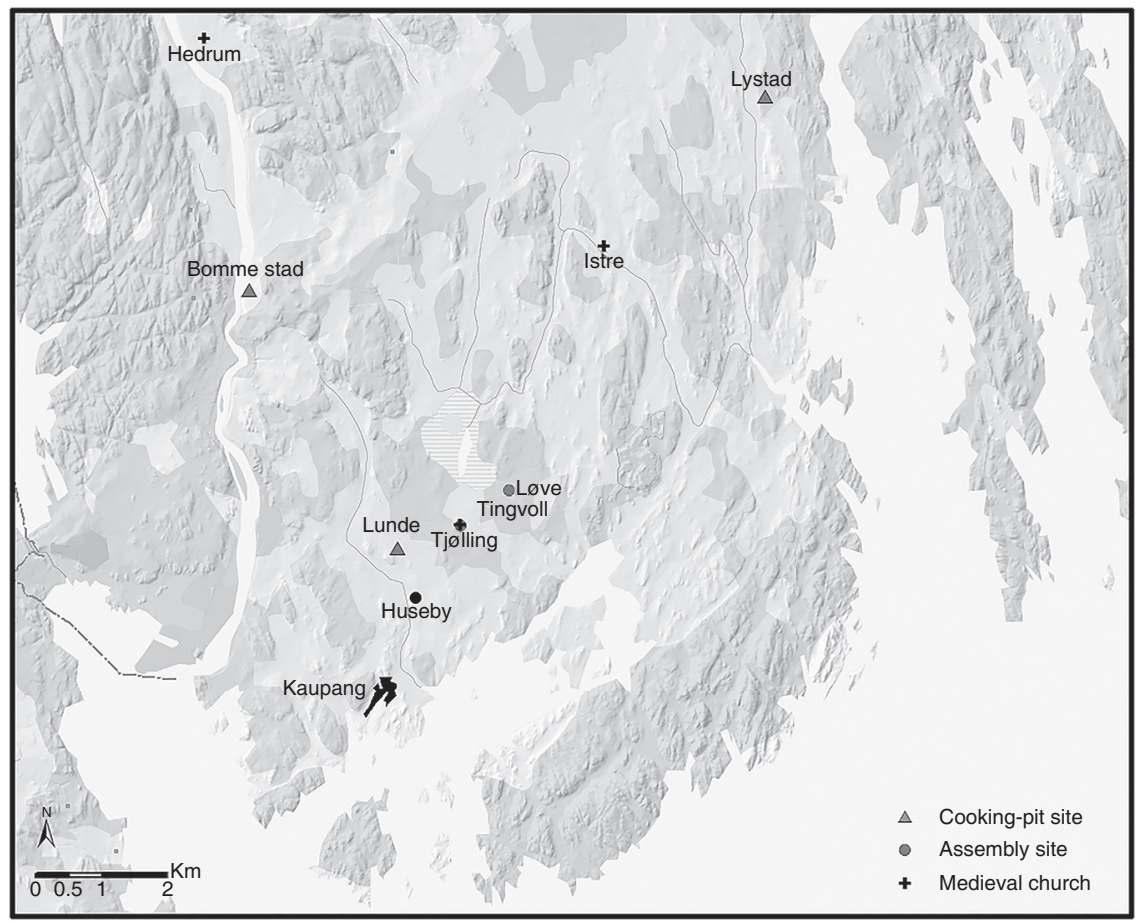

Figure 5.2 Sites referred to in the text (Marie Ødegaard)

thing-sites, especially when used in conjunction with toponymic evidence. Thingsites can be divided into two categories, certain and possible. Several late medieval documents use the term 'correct thing-site' (ON réttr pingstaðr), in other words a legally recognised site; this is an important indication of the sites' established position. The 'correct thing-sites' constitute the majority of certain thingsites, and the term may also have signified continuity over longer periods. Some diplomas - that is letters and documents with legal force, dated to between the 13th and the 17th centuries - use the Old Norse term stefna (i.e. assembly), which does not necessarily refer to legally recognised sites; sites so-called are therefore categorised as possible thing-sites, along with those indicated by place-names. Place-names may provide information about meeting-places, perhaps with cultic and/or legal functions, from the Viking Age or even earlier.

Assemblies were closely related to administrative areas at different levels. The medieval administrative units have been mapped in order to understand different levels of the assembly organisation, based on historical sources and earlier research. ${ }^{11}$ The Borgarthing law area consisted of four geographical and

11 J. Agerholt, 'Embetsdistrikter i Østfold fra det 16. århundre til det 20', Tidsskrift utgitt av Østfold Historielag, 2 (1951), 149-83; E. Bull, Leding. Militcer- og finansforfatning i Norge $i$ celdre tid (Kristiania and Copenhagen, Steenske Forlag, 1920); G. Indrebø, 'Spreidde merknader um dei norske logmannsembætti i millomalderen', Historisk Tidsskrift, 30 (1934-6), 489-524; J. H. Marthinsen, 


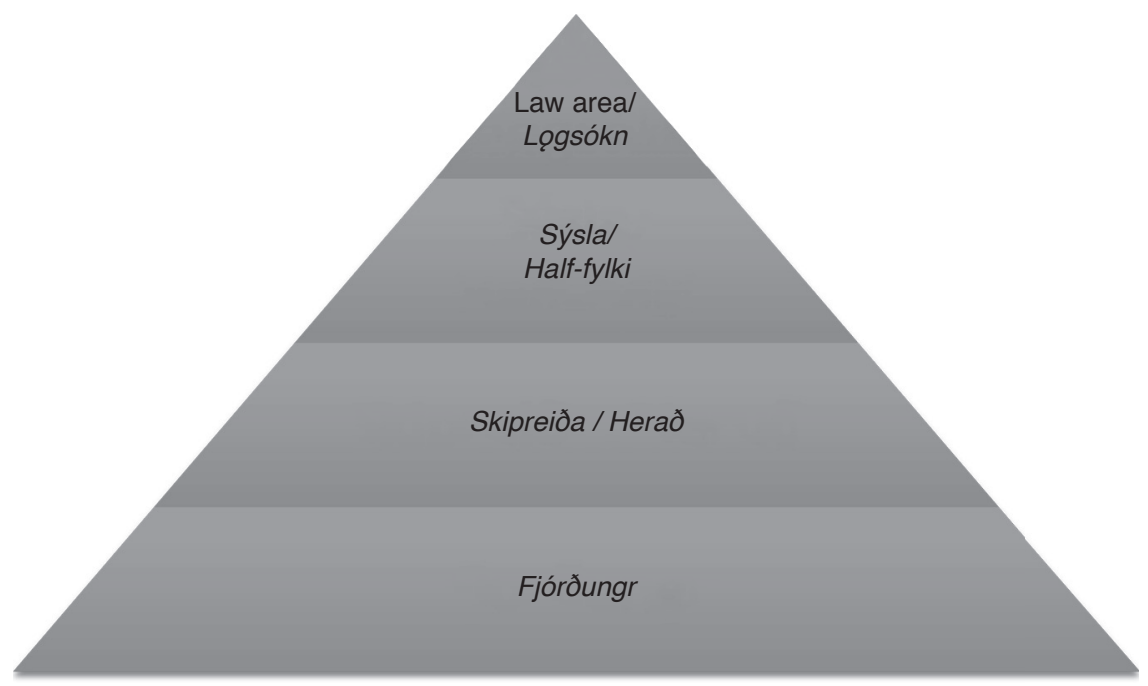

Figure 5.3 The different geographical and hierarchical levels in the Borgarthing law area (Marie Ødegaard)

hierarchical levels in the late Middle Ages. At the top was the law area itself, which was divided into sýslur (sg. sýsla). The above-mentioned skipreiður, which were subdivisions of the sýslur, were again divided in quarters called fjórðungar (sg. fjórðungr) (Figure 5.3). ${ }^{12}$ Within these areas were assembly sites at different levels and functions. According to the older Christian laws of the Borgarthing, ${ }^{13}$ dated to the first half of the 11 th century, ${ }^{14}$ there existed a system of so-called fylkichurches (i.e. main churches) in this region. In total, six churches are mentioned; each half-fylki had one church. ${ }^{15} \mathrm{~A}$ half-fylki corresponded to the aforementioned sýsla-division. It is likely that the sýslur displaced the older fylki areas. ${ }^{16} \mathrm{~A}$ sýsla

'Kart over administrative grenser 1647 og 1970-åra', in R. Fladby and H. Winge (eds), Den eldste matrikkelen: en innfallsport til historien: skattematrikkelen 1647 (Oslo, Universitetsforlaget, 1980), pp. 59-78; P. A. Munch, Historisk-geographisk Beskrivelse over Kongeriget Norge (Norgesveldi) $i$ Middelalderen (Moss, Gram, 1849); A. Steinnes, Gamal skatteskipan i Noreg II (Oslo, Jacob Dybwad, 1933).

12 P. S. Andersen, 'Syssel', in Kulturhistorisk Leksikon for Nordisk Middelalder. Fra vikingtid til reformasjonstid, 17 (Copenhagen, Rosenkilde og Bagger, 1982), pp. 645-8; Andersen, 'Ting', pp. 348-9; Bjørkvik, 'Skipreide', pp. 546-50; G. Indrebø, Fjordung. Granskingar i eldre norsk organisasjons-soge, Historisk-antikvarisk rekke, 1 (Bergen, Bergens Museums Årbok, 1935).

13 Older Christian laws of the Borgarthing, ch. 8; M. Rindal, 'Borgartings eldre kristenrett', in E. F. Halvorsen and M. Rindal (eds and trans.), De eldste østlandske kristenrettene, Norrøne tekster, 7 (Oslo, Riksarkivet, 2008), pp. 117-236. The churches are Hedrum and Sem in Vestfold county, Aker and Tune in Vingulmork county and Svarteborg and Konghelle in Ranrike county. Cf. figure 5.8.

${ }^{14}$ M. Rindal, 'Innleiing', in Halvorsen and Rindal (eds and trans.), De eldste østlandske kristenrettene, pp. xxi-Xxxvi at xxiii.

${ }^{15}$ A. Taranger, 'Om Betydningen av Herads og Herads-Kirkja i de ældre Kristenretter', Historisk tidsskrift, R 2.6 (1888), 337-401 at 338.

16 P. Norseng, 'Borgarsysle', in P. Norseng, and S. G. Eliassen (eds), I Borgarsysle. Østfolds historie, 2 (Sarpsborg, Østfold Fylkeskommune, 2005), pp. 12-334 at 62-4; M. Ødegaard, 'State Formation, 
was an administrative area that the king gave to his faithful men as fief, perhaps in the 11th century. The sýsla represented a new form of royal control, where royal officials were put in place to enforce the law, for military defence purposes and, later, for tax collection. ${ }^{17}$

The skipreiður contained four thing-sites, one in each fjórðungr, constituting the rural thing-sites of the Borgarthing law area. ${ }^{18}$ One of them functioned at a higher level, as a common thing for the whole skipreiða area. Both types of assemblies are assumed to be 'althings', where all free men would meet. ${ }^{19}$ The skipreiður divisions mapped onto an older division of heruð (sg. herað) units, which may have been introduced in this area before the 11th century by Danish kings. ${ }^{20}$

\section{The Characteristics of Large Cooking-Pit Sites}

Large cooking-pit sites are relatively rare, but have been found over a large geographical area, predominantly northern Germany, southern Scandinavia and south-eastern Norway. The Norwegian sites are often irregularly structured and relatively late in date, mostly dated to $\mathrm{AD} 0-600$. In contrast, the northern German and southern Scandinavian sites are often linear, with one or more rows of pits, and dated to the Bronze Age or, in some cases, to the early Iron Age. ${ }^{21}$ Since the sites are relatively few in number, they seem to have been used only on special occasions when many people gathered and large quantities of food were needed.22

Administrative Areas, and Thing Sites in the Borgarthing Law Province, Southeast Norway', Journal of the North Atlantic, Special Volume 5, Debating the Thing in the North I: The Assembly Project, ed. A. Sanmark, F. Iversen, N. Mehler, and S. Semple (2013), 42-63 at 45-6.

${ }_{17}$ Stylegar and Norseng, 'Del 2', p. 404.

${ }^{18}$ Cf. Indrebø, Fjordung, pp. 136-68; J. Sandnes, 'Tingsted', in Kulturhistorisk Leksikon for Nordisk Middelalder, fra vikingtid til reformasjonstid, 3 (Copenhagen, Rosenkilde og Bagger, 1982), pp. $379-81$ at 380 .

19 E.g., Indrebø, Fjordung; Norseng, 'Borgarsysle', p. 257.

${ }^{20}$ E.g., E. Bull, 'Studier over Norges administrative inddeling i middelalderen', Historisk Tidsskrift, R 5.4 (1918), 257-82; S. B. Sogner, 'Herred,' in Kulturhistorisk Leksikon for Nordisk Middelalder. Fra vikingtid til reformasjonstid, 6 (Copenhagen, Rosenkilde og Bagger, 1981), pp. 492-4; S. Tunberg, Studier rörande Skandinaviens äldsta politiska indelning (Uppsala, K. W. Appelbergs boktryckeri, 1911).

${ }^{21}$ Gustafsen, 'Om kokegroper i Norge', p. 105; S. Heidel-Schacht, 'Jungbronzezeitliche kultfeuerplátze im Norden der DDR', in F. Schlette and D. Kaufmann (eds), Religion und Kult in ur- und frühgeschichtlicher Zeit (Berlin, Akademie-Verlag, 1989), pp. 225-40; Henriksen, 'Bål i lange baner', 90-2, 112; R. Thörn, 'Rituella elder. Linjära, konkava och konvexa spar efter ritualer inom nord- och centraleuropeiska brons- och järnålderskulturer', in K. Engdahl and A. Kaliff (eds), Religion från stenålder till medeltid. Artiklar baserade på Religionsarkeologiska nätverksgruppens konferens på Lövstadbruk den 1-3 december 1995, Riksantikvarieämbetet Arkeologiska undersökningar, Skrifter, 19 (Linköping, Riksantikvarieämbetet, 1996), pp. 135-48.

${ }^{22}$ L. Gustafson, 'En kokegrop er en kokegrope er en ...?', Follominne, 37 (1999), 6-13; Henriksen 'Danske kogegruber og kogegrubefelter', p. 98; L. Pilø, Bosted-urgård-enkeltgård. En analyse av premissene $i$ den norske bostningshistoriske forskningstradisjonen på bakgrunn av 
Experiments have shown that food for thirty to fifty people could be prepared in these round cooking-pits. ${ }^{23}$ If kept closed when not in use, the pits could be used repeatedly over several days.

It is difficult to determine how many pits were in use simultaneously and for how many people they catered. According to the laws of Olaf in the Old Gulathing law (\$3), 400 representatives met at the law-thing. If a similar number was present at the cooking-pit sites once a year and one cooking-pit could cover the food need for thirty people, thirteen pits per gathering were required, or eight pits if the estimate of fifty is used.

Thing meetings may have lasted from a few days up to several weeks. Paragraph 4 in the Old Gulathing law relates that one male thrall was to be emancipated the 'first Sunday', indirectly suggesting that the thing could last more than a week. The length of time of an assembly also seems to have been adjusted according to the number of cases. ${ }^{24}$ Durations of several days and weeks are also known from other large thing meetings, such as the Irish óenach (6th-10th centuries) and the Icelandic Althing (later in the Middle Ages). ${ }^{25}$

The cooking-pit sites have been interpreted as evidence of cult practices, especially sacrifice. ${ }^{26}$ This has invited comparison with Tacitus' description of a Germanic cult site in a 'holy grove', ${ }^{27}$ leading to discussions about possible continuity of cult practices and sites. ${ }^{28}$ As discussed above, others have interpreted them as sites for gatherings with judicial functions - early forms of thing-sites. ${ }^{29}$ Their age indicates that they should be interpreted as communal structures rather than connected to supra-regional royal power that emerged after the 9th century in Norway.

The location and topography of these sites are central issues when discussing their functions. In particular, isolated and prominent locations and proximity to

bebyggelsesarkeologisk feltarbeid på Hedemarken, Oslo Archaeological Series, 3 (Oslo, Institutt for arkeologi, kunsthistorie og konservering, Universitetet i Oslo, 2005), p. 292 n. 526.

${ }^{23}$ Thirty people could be fed from a cooking-pit with a diameter of $1 \mathrm{~m}$ and a depth of $0.5 \mathrm{~m}$ (Pilø, Bosted-urgård-enkeltgård, p. 292 n. 526). Skre, however, seems to argue that one pit could feed fifty persons (Skre, Kaupang in Skiringssal, p. 403).

${ }_{24}$ Magnus Lagabøters Landslov, trans. A. Taranger (Kristiania, 1915), III, 1.

${ }^{25}$ N. Staf, Marknad och möte. Studier rörande politiska underhandlingar med folkmenigheter $i$ Sverige och Finland intill Gustav II Adolfs tid (Stockholm, A. Börtzells Tryckeri, Esselte AB, 1935), p. 225; D. A. Binchy, 'The Fair of Tailtui and the Feasts of Tara', Ériu, 18 (1958), 113-38 at 115, 122; J. Jóhannesson, A History of the Old Icelandic Commonwealth: Íslendinga Saga, Icelandic Studies, 2 (Winnipeg, University of Manitoba Press, 1974), pp. 44-5.

${ }^{26}$ Henriksen, 'Bål i lange baner'; Narmo, 'Kokekameratene på Leikvin'.

${ }^{27}$ C. Tacitus, Germania, trans. J. G. C Anderson (Oxford, Clarendon Press, 1938), ch. 39.

${ }_{28}$ Narmo, 'Kokekameratene på Leikvin'; Oma, 'Fasanhagen, Lystad'; G. Reitan, 'Våle prestegård, 94/1, Våle kommune, Vestfold’ (unpublished excavation report, University of Oslo, Museum of Cultural History Archive, 2001); G. Reitan, 'Fra kokegroper til halshogging på Faret—bruk og gjenbruk av kultsted gjennom 1600 år', in Gustafson et al. (eds), De gåtefulle kokegroper, pp. 177-88; K. Stene, 'Slagen kirkegård, Bøe søndre, 98/47, Tønsberg kommune, Vestfold' (unpublished excavation report, University of Oslo, Museum of Cultural History Archive, 2002); K. Stene, 'Kokegropene på Våle prestegård'.

${ }^{29}$ Skre, Kaupang in Skiringssal, pp. 385-406; Gjerpe, Kulturhistoriske, metodiske og administrative erfaringer, pp. 56-7. 
water are seen as important features. ${ }^{30}$ Scholars have also questioned whether the sites should be seen as expressions of intensive activities within a short time span, or if they represent more sporadic activities over the course of several centuries. Since the cooking-pits often respect each other spatially, it has been assumed that the activities took place within a limited period. ${ }^{31}$

In Norway, the sites appear to have fallen out of use at the end of the 6th century. This is a period of significant cultural-historical changes in Europe, ${ }^{32}$ reflected in the archaeological record by developments in technology and ideology, settlement patterns and grave-goods: there are changes in the production of iron; the production of pottery ceases; a number of farms were laid waste; and the number of graves reduced significantly and they were less well equipped..$^{33}$ Ritual activities might have been moved closer to settlements, especially to central places, around $\mathrm{AD} 600,{ }^{34}$ and some of the sites' functions might have been taken indoors, into the halls of the elite. ${ }^{35}$ One issue to be investigated, then, is whether such changes might be related to a spatial division of functions, whereby the different, previously integrated components of the cooking-pit sites - cultic, juridical and military functions - were dispersed to different locations. ${ }^{36}$ Such changes might have been the result of changing internal military structures and increasing levels of control by magnates. The cessation in use of the pit sites could perhaps be related to changing social structures in society, which might have made older meeting sites redundant.

\section{Cooking-Pit Sites in Southern Vestfold}

The cooking-pit site at the farm known as Lunde was discovered when a geophysical survey (GPR), carried out there in September 2010, revealed 750 anomalies. The survey was undertaken by the Ludwig Bolzmann Institute for Archaeological Prospection and Virtual Archaeology (LBI ArchPro), the Norwegian Institute for

\footnotetext{
${ }^{30}$ Heidelk-Schacht, 'Jungbronzezeitliche kultfeuerplátze im Norden', p. 229; Henriksen, 'Bål i lange baner'; Martens, 'Kogegruber i syd og nord', pp. 42-3.

${ }^{31}$ Henriksen, 'Bål i lange baner', 112; Martens, 'Kogegruber i syd og nord', p. 41.

${ }^{32}$ H. Hamerow, Early Medieval Settlements: The Archaeology of Rural Communities in Northwest Europe, 400-900 (Oxford, Oxford University Press, 2002), p. 124.

${ }_{33}$ H. G. Gudesen, Merovingertiden i Øst-Norge: kronologi, kulturmønstre og tradisjonsforløp, Varia, 2 (Oslo, Universitetets Oldsakssamling, 1980), pp. 128, 138; Gustafson, 'Om kokegroper i Norge', p. 105; B. Solberg, Jernalderen i Norge. 500 før Kristus til 1030 etter Kristus (Oslo, Cappelen Akademiske Forlag, 2000), pp. 178-203; B. Myhre, 'Landbruk, landskap og samfunn 400 f.Kr.-800 e.Kr.', in B. Myhre and I. Øye (eds), Norges landbrukshistorie 1. 400 f.Kr.-1350 e.Kr. Jorda blir levevei (Oslo, Det norske samlaget, 2002), pp. 12-214 at 170-2.

${ }^{34}$ Henriksen, 'Danske kogegruber og kogegrubefelt', p. 99.

${ }^{35}$ F. Herschend, Livet $i$ hallen. Tre fallstudier $i$ den yngre järnålderns aristokrati, Occasional Papers in Archaeology, 14 (Uppsala, Uppsala universitet, 1997); Narmo, 'Kokekameratene på Leikvin'; D. Skre, Herredømmet. Bosetning og besittelse på Romerike 200-1350 e.Kr. (Oslo, Universitetsforlaget, 1998), p. 335

${ }^{36} \mathrm{Cf}$. Iversen this volume, Chapter 8.
} 
Cultural Heritage Research and Vestfold County Council, as part of an LBI ArchPro project. ${ }^{37}$ In May 2011, the Assembly Project (TAP), led by the Museum of Cultural History, University of Oslo, in collaboration with the LBI ArchPro project, conducted an excavation at the site..$^{38}$ This revealed that the greater majority of the observed geophysical anomalies appear to be consistent - both in terms of their number, size and location - and coincident with features interpreted through excavation as cooking-pits. However, these excavations also revealed other cooking-pits which were not visible on the geophysical plot. It is now estimated that there are at least 900-1000 pits, making the site one of the largest of its kind in Northern Europe (Figure 5.4). ${ }^{39}$ The aim of the excavation was to date the cookingpits, to ascertain whether they resulted from one large or several recurrent meetings, and whether the site could be linked chronologically to a thing at the neighbouring farm, Tjølling.

The Lunde site is at least 1.15 ha, but might extend further east. ${ }^{40}$ Excavations were made of selected anomalies of thirty pits distributed across the site, and identified from geophysical images (magnetic and GPR). The pits were staked out, with small trenches opened just above each one (Figure 5.5). To examine possible reuse of the pits, coal samples were taken from each layer or from the top and bottom of each pit. In total, thirty-eight dating samples were sent for Carbon 14 analysis.

The site is dated to $380 \mathrm{BC}$ to $\mathrm{AD} 630$, with a peak between $\mathrm{AD} 100$ and 400 (Table 5.1). The reuse of multiple pits several hundred years apart could be observed (Figure 5.6), signifying that the site was used repeatedly over a long time, conclusively countering the argument that activities were concentrated in a short period. ${ }^{41}$ Furthermore, simultaneous use of all of the pits at the large site of Lunde could have catered for 27,000-50,000 people, which seems more than a little unlikely. ${ }^{42}$ There are reasons to believe that the depressions of the pits must have been visible in the ground, since cooking-pits rarely overlapped. Small amounts of burnt bone were found, all from mammals, mostly from sheep or goats and cattle. ${ }^{43}$ The large number of cooking-pits, and the fact that the pits were reused, suggests a site employed by many people across centuries.

${ }^{37}$ L. Gustavsen, R. J. S. Cannell, E. Nau, C. Tonning, I. Trinks, M. Kristiansen, M. Gabler, K. Paasche, T. Gansum, A. Hinterleitner, V. Poscetti and W. Neubauer, 'Archaeological Prospection of a Specialized Cooking-Pit Site at Lunde in Vestfold, Norway', Archaeological Prospection, 25.1 (2018), 17-31. https://doi.org/10.1002/arp.1589.

${ }^{38}$ M. Ødegaard and F. Iversen, 'Kokegropfelt. Lunde, 1033/1, Larvik kommune, Vestfold fylke' (unpublished excavation report, Oslo, Museum of Cultural History Archive, 2011).

39 Ødegaard, 'Tingsted og territorium', p. 302.

40 So ha $=$ hectare. 100 hectares $=1 \mathrm{~km}^{2}$. A hectare of land is about 2.47 acres.

${ }^{41}$ Ødegaard, 'Tingsted og territorium', pp. 302-9.

42 See note 33. Many of the pits at Lunde also had larger diameter and depth than the ones used by Pilø.

${ }^{43}$ A. K. Hufthammer, 'Osteologisk rapport. C57824, Larvik k., Vestfold', in Ødegaard and Iversen, 'Kokegropfelt. Lunde'. 


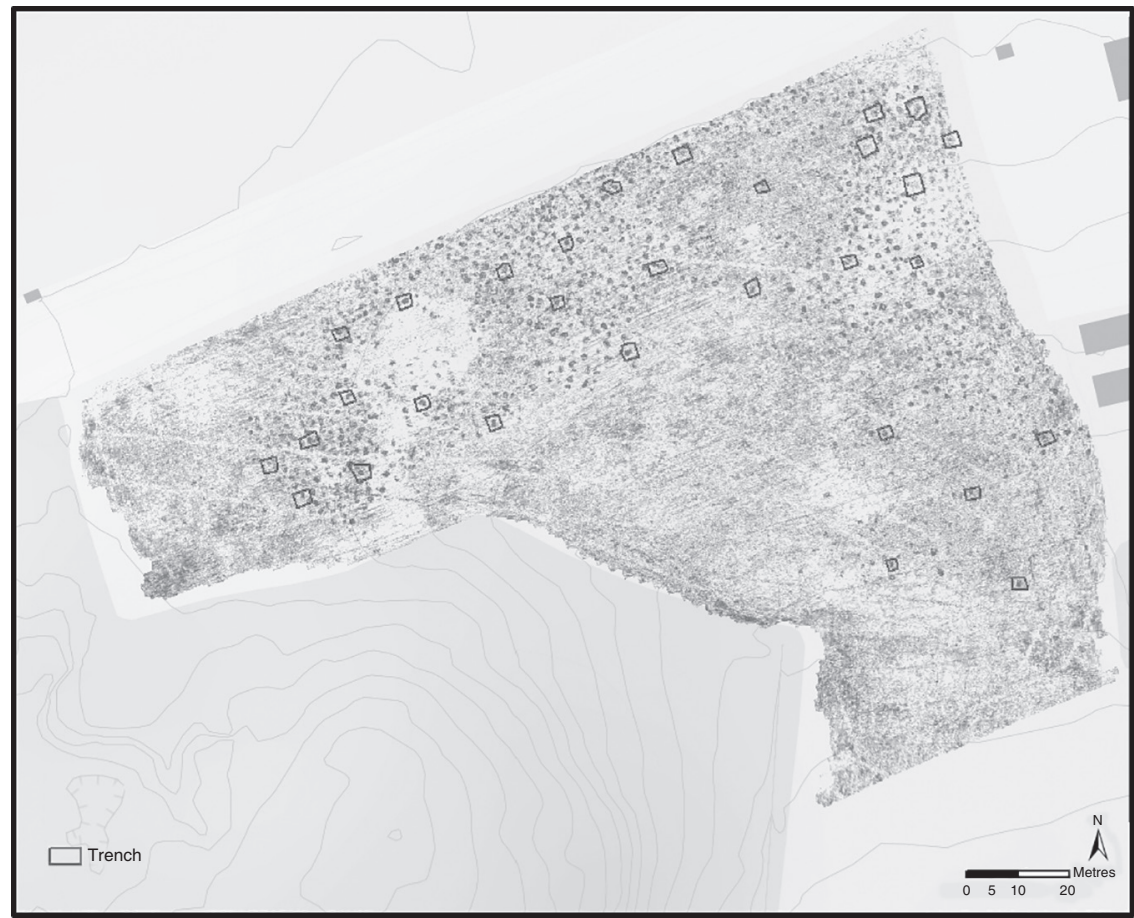

Figure 5.4 Cooking-pits at Lunde with the investigated pits and trenches (Marie Ødegaard)

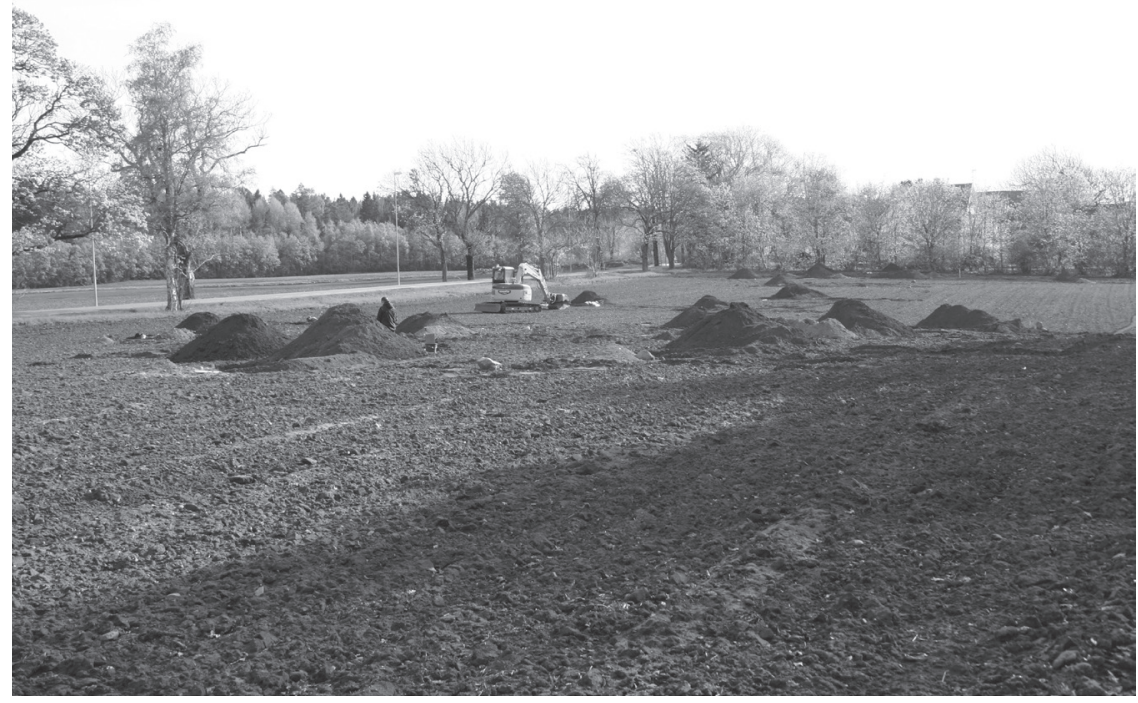

Figure 5.5 Opened trenches at the cooking-pit site, Lunde, with the farm in the background (Marie Ødegaard) 
Table 5.1 Radiocarbon dates from Lunde

OxCal v4.1.7 Bronk Ramsey (2010); r:5 Atmospheric data from Reimer et al (2009);

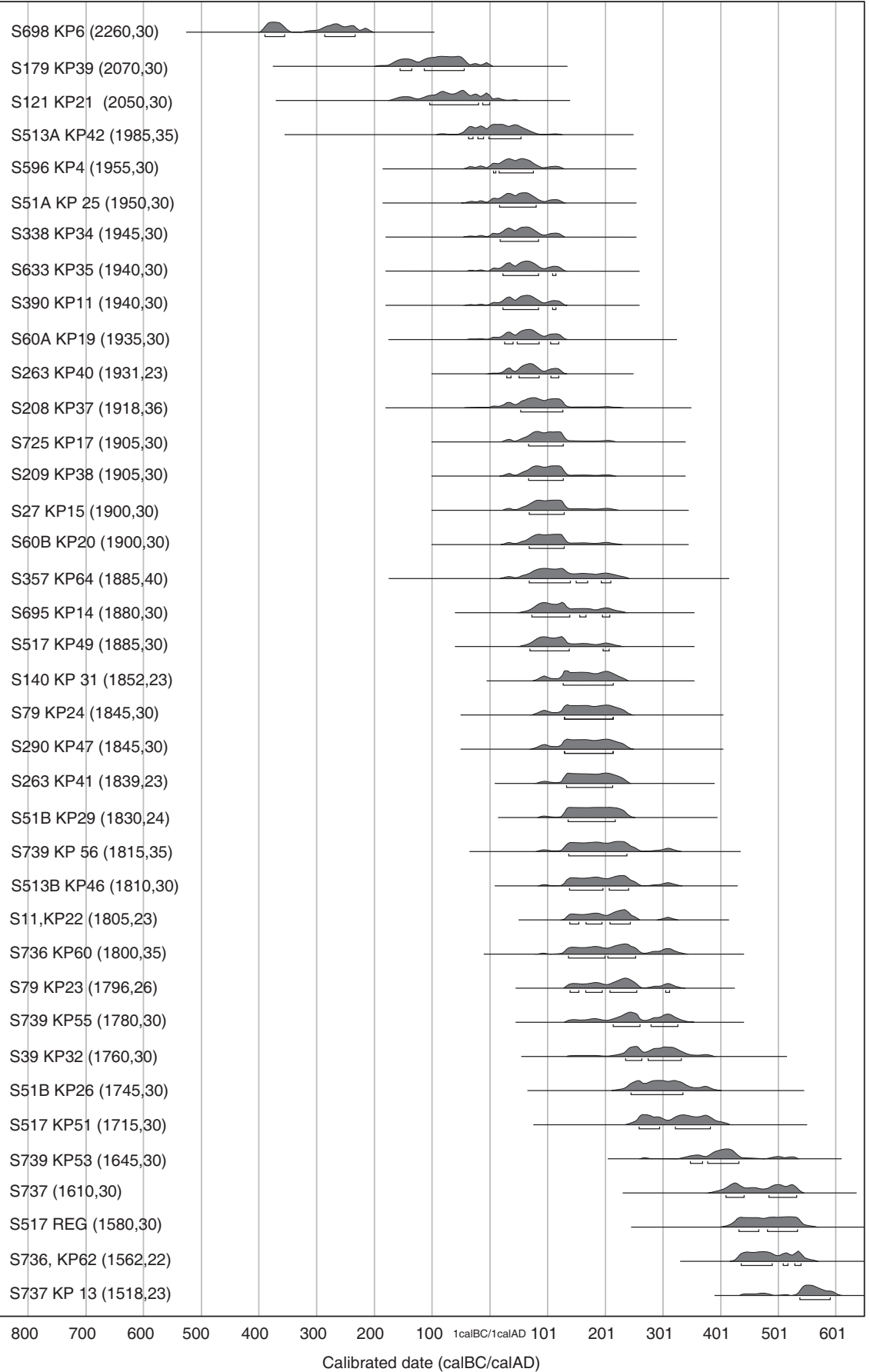




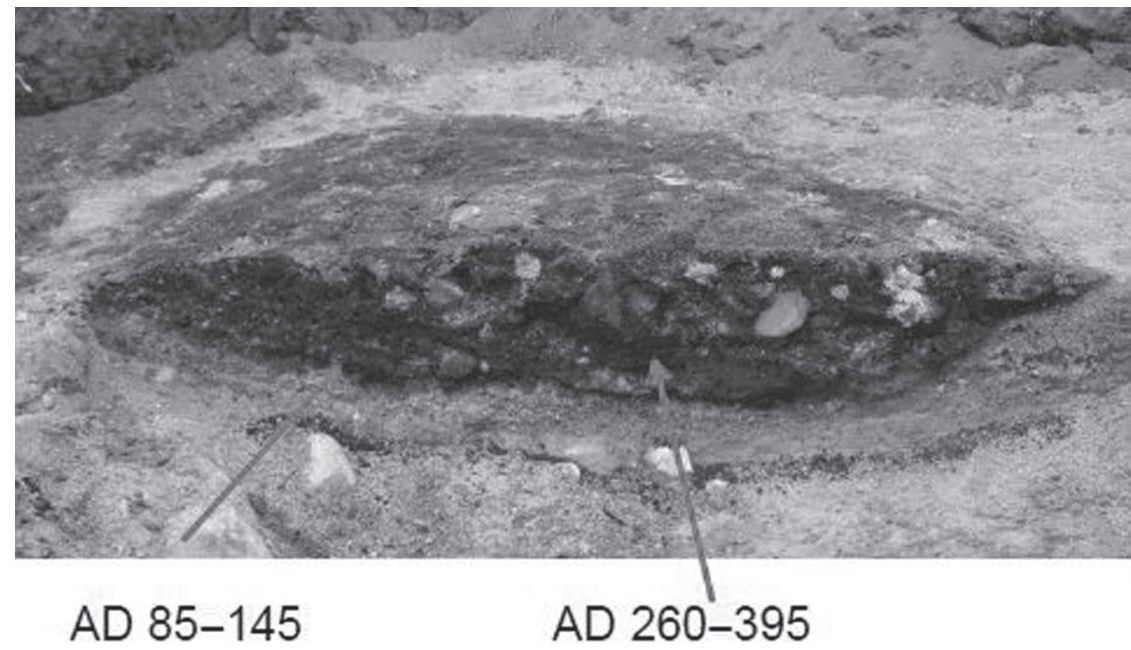

Figure 5.6 Several cooking-pits at Lunde had multiple layers, dated several hundred years apart, suggesting reuse of the pits (Marie Ødegaard)

Lunde is located close to the central place Skiringssal and the Viking Age town of Kaupang. ${ }^{44}$ Less than $1 \mathrm{~km}$ north-east is a medieval church at Tjølling..$^{45}$ The place-name Tjølling may derive from ON pjóðalyng, comprising a first element, pjóð 'people', and a second element, lyng 'heather'. ${ }^{46}$ The significance of pjó $\delta$ is debated..$^{47}$ It might denote a band, a people or even a nation. ${ }^{48}$ The name has been explained as 'heather, used as a thing-site', suggesting that assemblies were held there in the Viking Age and perhaps even earlier. ${ }^{49}$ There are, however,

${ }^{44}$ C. Blindheim, 'Kaupangundersøkelsen avsluttet', Viking, 33 (1969), 5-39; C. Blindheim and R. L. Tollnes, Kaupang, Vikingenes handelsplass (Oslo, Mortensen, 1972); C. Blindheim, B. Heyerdahl-Larsen and R. L. Tollnes, Kaupang-funnene, 1, Norske Oldfunn, XI (Oslo, Universitetets Oldsaksamling, Universitetet i Oslo, 1981); Kaupang-funnene, 2, Gravplassene i Bikjholbergene/ Lamøya. Undersøkelsene 1950-57. Del A. Gravskikk, Norske Oldfunn, 16 (Oslo, Universitetets Oldsaksamling, Universitetet i Oslo, 1995); Skre, Kaupang in Skiringssal.

45 Skre describes a 'specialised cooking-pit site' next to the church at Tjølling (Skre, Kaupang in Skiringssal, pp. 397-400). However, this site has only fifteen pits, hardly equivalent to a large cooking-pit site (cf. Gjerpe, Kulturhistoriske, metodiske og administrative erfaringer, p. 57). Furthermore, the site is mainly dated to the Bronze Age (1210-530 BC), although there is one pit dated to AD 250-430 and one dated to AD 610-680; A. Skullerud and J. Martens, 'Bosetningsspor. Tjølling prestegård, 1038/1, Larvik kommune, Vestfold fylke' (unpublished excavation report, Oslo, Museum of Cultural History Archive, 2009).

${ }^{46}$ O. Rygh, Norske Gaardnavne oplysninger samlede til brug ved matrikelens revision, 19 vols (Kristiania, Fabritius, 1833-99) [henceforth NG], VI, pp. 287-9.

${ }^{47}$ See, e.g., J. Fritzner, Ordbog over Det gamle norske Sprog, 4 vols (Kristiania, Feilberg \& Landmark, 1867), pp. 1024-5; NG VI, 287-9; G. Storm, 'Skiringssal og Sandefjord', Historisk Tidsskrift, R 4.1 (1901), 214-37 at 227; S. Brink, 'Skiringssal, Kaupang, Tjølling: The Toponymic Evidence', in D. Skre (ed.), Kaupang in Skiringssal. Kaupang Excavation Project, 22, 1 (Aarhus, Aarhus University Press, University of Oslo, 2007), pp. 53-64 at 63.

${ }^{48}$ Fritzner, Ordbog, 3, pp. 1024-5.

49 NG VI, 287-9. For the date of the name, see also Storm, 'Skiringssal og Sandefjord', 227; Brink, 'Skiringssal, Kaupang, Tjølling', 63. 
different opinions as to whether the name refers to a 'common rural thing-site' or a 'regional thing-site'. ${ }^{50}$ The church at Tjølling, dated to the first half of the 12th century, is special. With an area of 394 square metres, it was Eastern Norway's second largest basilica - a church-type that is relatively rare in Norway, especially outside towns, and in Scandinavia often connected to important sites. ${ }^{51}$ At Tjølling there is evidence of a thing meeting for a larger region, Southern Vestfold, in 1557. ${ }^{52}$ This suggests that people from a very extensive area gathered there..$^{53}$ The name Lunde may date to the Viking Age, and may denote a 'holy grove', which provides an interesting additional perspective on the range of possible functions of cooking-pit sites. ${ }^{54}$

The function and geographical range of the Lunde site is complicated by the fact that about $4.5 \mathrm{~km}$ north of Lunde another large cooking-pit site is located at the farm of Bommestad, excavated by the Museum of Cultural History in 2008 (Figure 5.2). ${ }^{55}$ This site is dated to the pre-Roman and Roman Iron Age (180 BC-AD 430 ) with a peak between $\mathrm{AD} 0-200$. The cooking-pits number around 550, but the site has not been fully excavated and probably extends to the south. Bommestad was well placed for long-distance communication, being located where roads and searoutes meet. ${ }^{56}$ The farm name, Bommestad, reconstructed as ON bundingsstaðir or bóndpingsstaðir, may be interpreted as 'farmer's thing-site', ${ }^{57}$ connecting the site to a later assembly. ${ }^{58}$ However, the precise signification of ON bóndi is uncertain. ${ }^{59}$

${ }^{50}$ Fritzner, Ordbog, 3, pp. 1024-5; Storm, 'Skiringssal og Sandefjord', 227.

51 J. Wienberg, 'Churches and Centrality: Basilicas and Hall-Churches in Medieval Scandinavia and Livonia', in A. Muntis (ed.), Lübeck style? Novgorod style? Baltic Rim Central Places as Arenas for Cultural Encounters and Urbanisation 1100-1400 AD: Transactions of the Central Level Symposium of the Culture Clash or Compromise (CCC) Project Held in Talsi September 18-21 1998, CCC Papers, 5 (Riga, Gotland University College, Centre for Baltic Studies, Nordik, 2001), pp. 269-303 at 279.

52 Diplomatarium Norvegicum. Oldbreve til Kundskab om Norges indre og ydre Forhold, Sprog, Slcegter, Sceder, Lovgivning og Rettergang i Middelalderen, ed. and trans. C. C. A. Lange, C. R. Unger et al., 22 vols (Christiania, 1847-1995) [henceforth DN], I, 1118. [Number (e.g. DN I, 543) always indicates the document number, not page.]

53 Skre, Kaupang in Skiringssal, p. 396.

${ }^{54}$ The name might only refer to a small forest; however, when it is next to a farm with a medieval church or heathen cult site, or have given name to a parish or a rural district, it is more likely to refer to a holy grove (J. Sandnes and O. Stemshaug, Norsk Stadnamnleksikon (Oslo, Det Norske Samlaget, 1976), p. 209), as can be seen here at Lunde.

${ }_{55}$ M. Samdal and G. B. Bukkemoen, 'Bommestad 2-kokegropfelt og dyrkningsspor fra jernalder', in L. E. Gjerpe (ed.), Hus, boplass- og dyrkningsspor. E18-prosjektet Vestfold, 3, Varia, 73 (Oslo, Kulturhistorisk Museum, 2008), pp. 247-64.

${ }^{56}$ Gjerpe, Kulturhistoriske, metodiske og administrative erfaringer, p. 56.

${ }^{57}$ NG VI, p. 342.

58 The Old Norse form is reconstructed from Bundingsstadum, that found in the late 14th-century source Biskop Eysteins Jordebok (Den røde Bog), trans. H. J. Huitfeldt-Kaas (Christiania, Gundersens bogtrykkeri, 1879). It is argued that the first element might be the genitive form of bóndaping, 'farmers' thing', found in the Old Christian laws for the Borgarthing area III 21 (R. Keyser, P. A. Munch, G. Storm and E. Hertzberg (eds), Norges Gamle Love indtil 1387, 5 vols (Christiania, Gröndahl, 1846-95) [NgL], I, 371), and also in Old Swedish as bondething (NG VI, p. 342). Proximity to the farm Tinghaugen (Thinghouffuen, 1664), 'Thing mound', may also support the explanation of the name Bundingsstaðir.

${ }^{59}$ Cf. Adolfsen, 'Maktforholdene på tingene' (unpublished MA thesis, University of Bergen, 2000), pp. 18-26; H. Bjørkvik, 'Bonde', in Kulturhistorisk Leksikon for Nordisk Middelalder. Fra vikingtid 
Etymologically, bóndi refers to any free man; ${ }^{60}$ however, in the regional laws of the Frostathing and Gulathing, it refers to a particular group of residential farmers, ${ }^{61}$ while the sagas often use it to denote a chieftain. ${ }^{62}$

In 2000 and 2006, two cooking-pit sites were excavated by the Museum of Cultural History on the farm of Lystad in Vestfold, $9 \mathrm{~km}$ east of Lunde (Figure 5.2). The sites are interpreted as the remains of one large entity with a total of 106 cooking-pits, but they have not been fully excavated and may be much larger. The pits have been dated to $50 \mathrm{BC}-\mathrm{AD} 445 .{ }^{63}$ The site is located around $800 \mathrm{~m}$ southeast of the Oslo fjord, on a flat stretch in a north-south oriented ridge, next to a small stream. The farm name Lystad, whose first element may derive from the river-name Lýsa 'bright, shining one', ${ }^{64}$ does not explicitly refer to an assembly site, and no medieval thing is known from this location. The cooking-pit site at Lystad probably went out of use around AD 450. It is difficult to argue for continuity in function here. Lystad had considerably fewer cooking-pits than the two other sites, had no place-names indicative of an assembly site or cultic associations, and is not centrally located with regards to communication routes. The site was probably a rural gathering place for a smaller area surrounding it.

The cooking-pit sites at Bommestad and Lunde have several similarities. Both were situated close to main roads, and extensively used in the Roman Iron Age. The number of cooking-pits on the two sites may indicate functions serving an extensive area. Bommestad had a central location in Numedal skipreiða, near a crossing point over the large River Lågen, which also gave its name to the skipreiða, thus perhaps offering clues to the extent of the region whose population attended the assembly there. There are, however, also differences between the two sites: Lunde had both a medieval church and a thing-site in immediate proximity, whereas Bommestad had neither.

The farm names Tjølling and Bommestad suggest that these sites may have continued to function as assembly places into the Viking Age, even if other possible functions moved to other locations or ceased altogether. There is a large time gap of (at least) two to three centuries between the cooking-pit sites falling out of use and the assumed Viking and medieval things appearing at Tjølling and

til reformasjonstid, 3 (Copenhagen, Rosenkilde og Bagger, 1980), pp. 89-95 at 87-95; T. Iversen, 'Die frühe norwegische Dingordnung zwischen Herrschaft und Genossenschaft', in T. Iversen, J. R. Myking and G. Thoma (eds), Bauern zwischen Herrschaft und Genossenschaft (Trondheim, Tapir Academic Press, 2007), pp. 167-86; F. Skrubbeltrang, 'Bonde', in Kulturhistorisk Leksikon for Nordisk Middelalder. Fra vikingtid til reformasjonstid, 3 (Copenhagen, Rosenkilde og Bagger, 1980), pp. 84-90 at 84-7.

${ }^{60}$ Fritzner, Ordbog, vol. 1, p. 62; K. Helle, Norge blir en stat 1130-1319 (Bergen, Oslo, Tromsø, Universitetsforlaget, 1974), p. 112.

${ }^{61}$ Bjørkvik, 'Bonde', 90; Iversen, 'Die frühe norwegische Dingordnung', pp. 4-7.

${ }^{62}$ Adolfsen, 'Maktforholdene på tingene', p. 20.

${ }^{63}$ W. Helliksen, 'Kokegroper. Fasanhagan-Solsletta, Lystad, 128/5, 187. Sandefjord kommune, Vestfold fylke' (unpublished excavation report, Oslo, Museum of Cultural History Archive, 2009); Oma, 'Fasanhagen, Lystad'.

${ }^{64}$ NG IV, p. 277. 
Bommestad, which does raise questions about continuity. Nevertheless, the possibility remains that the sites were used for assemblies within given areas that might have had their origins in early legal communities. It is likely that sharing food formed part of the resolution of conflicts and the forging of alliances, or other relations and activities.$^{65} \mathrm{Law}$, politics and religion seem to have been closely integrated at that time. Not least the sagas indicate that political considerations were integrated elements in decision-making at thing-sites. ${ }^{66}$ Therefore, large cooking-pit sites should be seen as the physical remains of feasts connected to thing meetings, where cultic, socio-political and military functions were combined.

\section{Lunde-A Regional Thing-Site?}

All three cooking-pit sites were located in the medieval skipreiða of Numedal in the southern part of Vestfold. Here, the medieval subdivisions are unknown, but it consisted of five so-called herred in the 19th century: Hedrum, Sandar, Brunlanes, Tjøme and Tjølling (Figure 5.7). ${ }^{67}$ Numedal skipreiða comprised ten parishes in the early medieval period. ${ }^{68}$ Lunde is located in Tjølling herred and parish in the south of Numedal skipreiða. Bommestad and Lystad are located in Hedrum and Sandar herred and parish respectively (see Figure 5.7).

Place-name evidence may shed light on differences in function between the cooking-pit sites of Lunde and Bommestad. The first element of the name Bommestad, ON bóndi, might refer to the foremost representatives of the farmers' community. ${ }^{69}$ In the Viking Age, chieftains arranged religious assemblies for the upper part of society at fixed times of the year, 'for prosperity and peace', in which thing meetings played an important part. ${ }^{70}$ This might imply that Bommestad was an assembly site for the elite. In comparison, the first element of the name Tjølling, ON pjóð, may indicate that this was an assembly for 'all', where

\footnotetext{
${ }^{65}$ Gjerpe, 'Kult, politikk, fyll'; Henriksen, 'Danske kogegruber og kogegrubefelt', 97-8.

${ }^{66}$ E. Adolfsen, 'Maktforholdene på tingene', p. 61.

${ }^{67}$ In 19th-century sources these areas are called herred, derived from ON heruð, but not necessarily referring to the same as the Viking Age and medieval heruð - the term was taken up again in the modern period and applied to administrative areas. As mentioned, it is assumed that the skipreiður succeeded the heruð and their geographical extent is the same in most part of Viken (Andersen, 'Ting', 348-9).

${ }^{68}$ Berg, Tanum, Kvelde, Hedrum, Kjose, Hvarnes, Istre, Tjølling, Sandar and Tjøme, in addition to most of Kodal parish in Andebu skipreiða.

${ }^{69}$ Adolfsen, 'Maktforholdene på tingene', 20-6; H. Koht, 'Sagaernes opfatning av vor gamle historie', Historisk Tidsskrift, R 5.2 (1914), 379-96; P. A. Munch, Det norske Folks Historie, I (2) (Christiania, Tønsbergs forlag, 1853), p. 304; G. Sandvik, Høvding og konge i Heimskringla, Avhandlinger fra Universitetets historiske seminar, 9 (Oslo, Akademisk Forlag, 1955), p. 45.

${ }^{70}$ Saga Ólafs hins helga, in En kort Saga om Kong Olaf den Hellige fra anden Halvdeel af det tolfte Aarhundrede, ed. and trans. R. Keyser and C. R. Unger (Christiania, Feilberg and Landmark, 1849), ch. 77.
} 


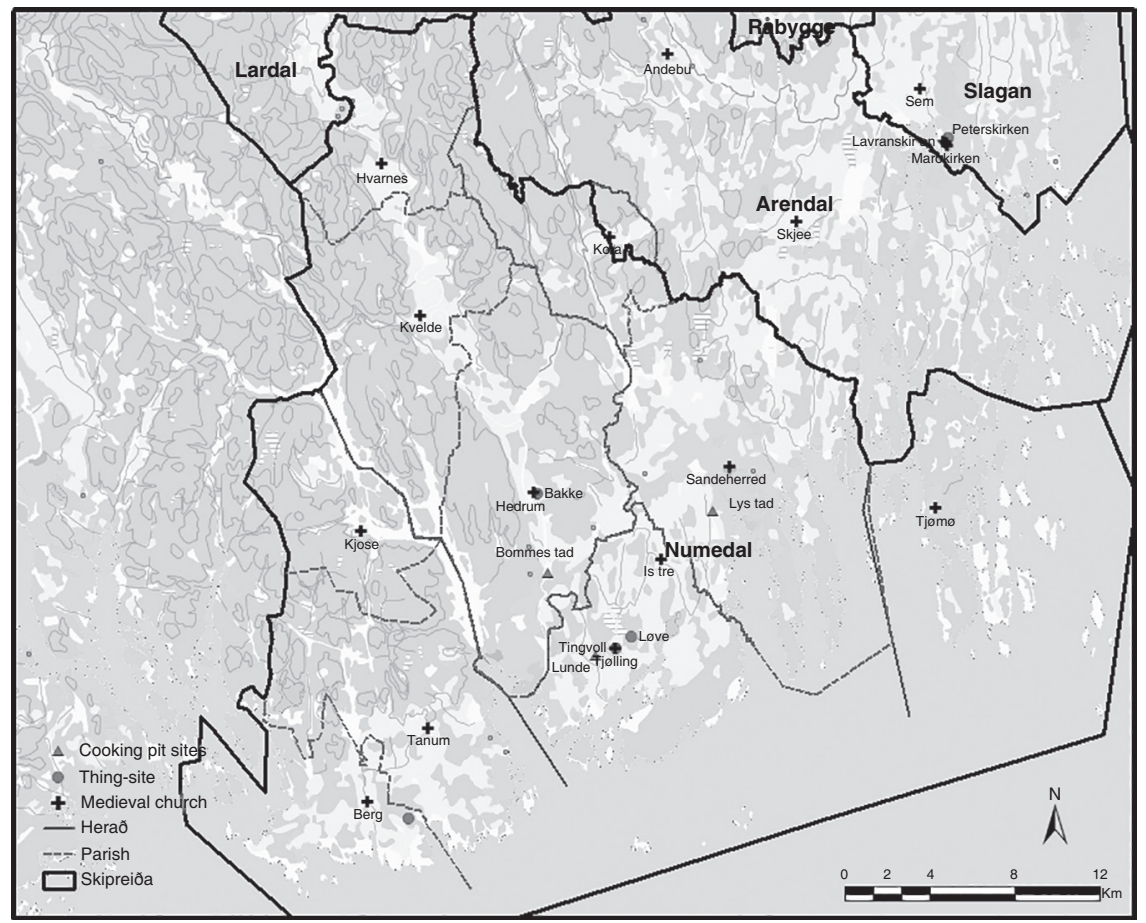

Figure 5.7 The investigation area, Numedal skipreiða, with heruð and parish boundaries, cooking-pit sites, medieval churches and thing-sites (Marie Ødegaard)

people who came from a large area gathered. ${ }^{71}$ The two names may thus suggest assemblies with different constituencies and functions.

The cooking-pit site went out of use in the 7th century. The name might nevertheless indicate that the thing was sustained at Tjølling in the subsequent period. Tjølling was an important site in the region at that time, consisting of the central place Skiringssal. Together with a Viking Age hall on the neighbouring farm, Huseby, and a thing-site near the later church at Tjølling, this constituted a complex of central functions. ${ }^{72}$ Later, in the 9th century, the Viking town Kaupang was established south of Lunde. The name Huseby indicates that this place was a royal administrative farm between the 10th and 13th centuries. ${ }^{73}$ A corner-timbered

${ }^{71}$ Brink, 'Skiringssal, Kaupang, Tjølling', p. 63.

72 The area around Lunde has been thoroughly discussed in the Kaupang publications (Blindheim, Kaupangundersøkelsen; Blindheim and Tollnes, Kaupang, Vikingenes handelsplass; Blindheim, Heyerdahl-Larsen and Tollsnes; Skre, Kaupang in Skiringssal, pp. 223, 440-2), however the cooking-pit site was not known at that time.

${ }^{73}$ L. E Christensen, T. Lemm and A. Pedersen, Husebyer: Status Quo, Open Questions and Perspectives: Papers from a Workshop at the National Museum, Copenhagen, 19.-20. March 2014 (Copenhagen, National Museum of Denmark, University Press of Southern Denmark, 2016); F. Iversen, 'The Urban Hinterland: Interaction and Law-Areas in Viking and Medieval Norway', in Z. T. Glørstad and K. Loftsgarden (eds), Viking-Age Transformations: Trade, Craft and Resources in Western 
building, probably succeeding the hall, might be related to the Huseby farm's function as a royal administrative unit. ${ }^{74}$ That thing-sites were located next to elite residences and central places is well attested in Scandinavia. ${ }^{75}$ At the end of the 10th century, Kaupang was abandoned and it seems as if the Tjølling chieftains lost their power. The large stone basilica at Tjølling testifies to the area's continued importance for gatherings in the Middle Ages, which is further demonstrated by the regional assembly held at the church in the 16th century.

In Numedal, two possible medieval thing-sites are known, Hedrum and Løve (Figure 5.7). The thing-site at Tjølling church is indicated only by the aforementioned document of 1557, which describes how peasants from Southern Vestfold met there. This implies convincingly that it was a regional assembly. The large stone basilica at Tjølling had extensive income in the Middle Ages. It has therefore been suggested that the church functioned as the fylki-church of the region, ${ }^{76}$ even though, according to the laws, the fylki-church was located at Hedrum, further north. Certainly, Hedrum is in the middle of the skipreiða, but the population was clearly concentrated in its southern part. There is nothing to indicate that large assemblies were held at the fylki-church at Hedrum. On the contrary, evidence for a regional assembly is known only from Tjølling. The fylkichurches were probably erected by the king, ${ }^{77}$ but there is nothing to suggest that this was the case with the basilica at Tjølling. It may thus have been built by the congregation as members of a thing community. ${ }^{78}$ Churches closely related to law-thing sites are also known from Gulathing and Frostathing ${ }^{79}$ as well as the fylki-churches and sýsla things in the Borgarthing law province. ${ }^{80}$ In Sweden, several churches are built on thing-sites common for a district. ${ }^{81}$ Tjølling was an important place for assembly throughout the Iron Age and early Middle Ages. The church at Hedrum seems to have continued with functions within the local area, attested by the presence of a 'certain' thing-site at Hedrum's neighbouring farm in the 14 th and 15 th centuries. ${ }^{82}$

Scandinavia (Oxford, Routledge, 2017), pp. 250-76; A. Steinnes, Husebyar (Oslo, Grøndahl \& Søn, 1955); F.-A. Stylegar and C. Westerdahl, 'Husebyene i Norden', Viking, 67 (2004), 101-38.

74 Skre, Kaupang in Skiringssal, p. 246.

75 Andersen, 'Ting', pp. 348-9; S. Brink, 'Political and Social Structures in Early Scandinavia [1]: A Settlement-historical Pre-study of the Central Place', Tor 28 (1996), 235-81; M. Ødegaard, 'Thing Sites, Cult, Churches, Games and Markets in Viking and Medieval Southeast Norway, AD c.800-1600.' World Archaeology, 50:1 (2018), 150-64. https://doi.org/10.1080/00438243.2018.1488610.

${ }^{76}$ Skre, Kaupang in Skiringssal, pp. 394-5.

77 J. Sandnes, 'Fylkeskirkene i Trøndelag i middelalderen. En del notater og detaljmateriale', Arbok for Trøndelag (1969), 116-36 at 118.

78 Skre, Kaupang in Skiringssal, pp. 395-6.

${ }^{79}$ Frostatingslova (The law of the Frostathing), trans. J. R. Hagland and J. Sandnes. Norrøne bokverk (Oslo, Det norske samlaget, 1994), I, 3; J. R. Hagland and J. Sandnes (trans.), 'Om lova og lagdømmet', in Frostatingslova, IX-LI at xxvi.

${ }^{80}$ Ødegaard, 'Tingsted og territorium', 331-2.

${ }^{81}$ S. Brink, Sockenbildning och sockennamn. Studier $i$ äldre territoriell indelning $i$ Norden, Acta Academiae Regiae Gustavi Adolphi, 57, Studier till en svensk ortnamnsatlas, 14 (Uppsala, Uppsala Universitet, 1990), pp. 1-449 at 73-175.

${ }^{82}$ On the farm of Bakke, a farm that has now become part of the vicarage. DN I, 397/ 1367; DN II, 739/1440; DN II, 770/1446. 
The other thing-site in Lunde's vicinity was located on the farm of Løve, approximately $1.8 \mathrm{~km}$ to the east, and categorised as a 'certain' thing-site from at least the 14th and 15 th centuries. ${ }^{83}$ Additionally, at Løve there is a holding with the name Tingvoll, ${ }^{84}$ comprising ON ping 'assembly' and vollr 'flat grassland'. Reflexes of ON ping-vollr are often used in place-names for assembly sites, as at Tingvalla (Karlstad, Sweden) and Pingvellir (Iceland). ${ }^{85}$ In this case, the placename may date the assembly further back in time than the written documents testify and point to the thing's exact location.

The place-names Tjølling and Tingvoll at Løve probably both referred to Viking Age assemblies, ${ }^{86}$ and there is a possibility that the assembly at Lunde was moved to Tingvoll when Kaupang was abandoned in the mid-10th century. However, the material seems to indicate that Tingvoll at Løve was the rural assembly of the local district, while Lunde and Tjølling were higher-level assemblies serving a larger geographical area in the Iron Age and medieval period.

A description of a large political meeting in Bergen in 1223 might shed light on the nature of the legal community in Viken before the expansion of supraregional royal power. As mentioned above, the oldest secular sources for Viken indicate three fylki here, ${ }^{87}$ generally assumed to be Vestfold, Vingulmork and Ranrike. ${ }^{88}$ According to the saga of Haakon Haakonsson, two law men (sg. logmaðr) from Viken attended. One of them came 'east from Svinesund', ${ }^{89}$ an area corresponding to Ranrike fylki, present Bohuslän in Sweden (Figure 5.8). The western border and the inclusion of the area of Grenland have been debated in this context, and the sources are ambiguous. The Latin source Historia Norwegie, dated to around $1160-75,,^{0}$ indicates that Grenland was a part of Viken as a judicial district (provincie) at that time, probably reflecting older traditions. ${ }^{91}$ The judicial district

${ }^{83}$ DN I, 406/1370; DN III, 649/1419; DN XI, 81/1391; DN XI, 89/ 1397.

${ }^{84} \mathrm{MA}=$ Matrikkelutkastet 1950, http://www.dokpro.uio.no/cgi-bin/stad/matr50 (accessed 14 February 2000).

${ }^{85}$ Brink, 'Skiringssal, Kaupang, Tjølling', 60.

${ }^{86}$ Brink 'Skiringssal, Kaupang, Tjølling', 63; J. Sandnes, 'Gards- og andre bustadnamn', in J. Sandnes and O. Stemshaug (eds), Norsk Stadnamnleksikon (Oslo, Det Norske Samlaget, 1976), pp. 28-33 at 31; Sandnes and Stemshaug, Norsk Stadnamnleksikon, p. 314.

${ }^{87}$ A fragment of the secular laws for Eastern Norway indicates that the area originally consisted of three counties (NgL II, 523; Rindal, 'Borgartings eldre kristenrett', p. 228). This fragment has been dated to the 14th century (Rindal 'Innleiing'), however, it has been assumed that the section belongs to the middle of the 11th century (Dørum, Romerike og riksintegreringen, p. 393).

${ }^{88}$ E. F. Halvorsen, 'Innledning', in E. F. Halvorsen and M. Rindal (eds and trans.), De eldste østlandske kristenrettene, Norrøne tekster, 7 (Oslo, Riksarkivet, 2008), p. 133; G. Indrebø, 'Fylke og fylkesnamn', Bergen Museum aarbok, 1 (1931), 3-54.

${ }_{89}$ Austr fra Suinasundi; Haakon Haakonssons saga, in S. Sturluson, Kongesagaer, trans. and ed. S. Porðarson and F. Hødnebø, Norges kongesagaer, 4 (Oslo, Gyldendal Norske Forlag, 1979), pp. 89-97 (ch. 94), p. 97. Svinesund is a seaway separating the Norwegian and Swedish realms today.

${ }^{90}$ L. B. Mortensen, 'Introduction', in I. Ekrem and L. B. Mortensen (trans. and eds), Historia Norwegie, trans. P. Fisher (Copenhagen, Museum Tusculanum Press, 2003), pp. 8-48.

${ }_{91}$ Ødegaard 'Tingsted og territorium', pp. 89-90. 


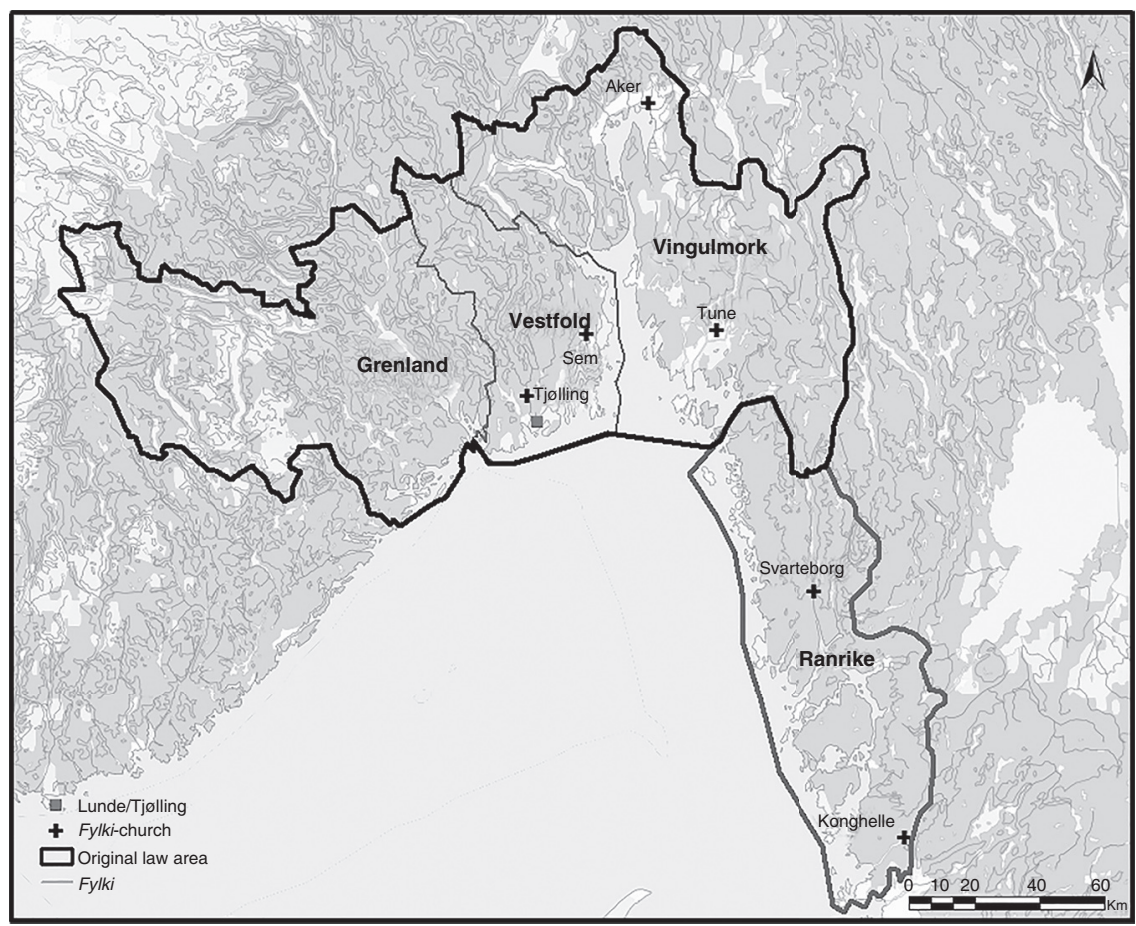

Figure 5.8 The four fylki (counties) in Viken with fylki-churches. An original juridical district consisting of Grenland, Vestfold and Vingulmork is suggested (Marie Ødegaard)

or law-parish (logsókn) of the second law man was Vingulmork, ${ }^{92}$ Vestfold and Grenland. This indicates that one law man only had jurisdiction in Ranrike-a considerably smaller region than the rest of the law area. Ranrike might also have been under Danish rule or influence earlier and for a longer period than the rest of Viken. ${ }^{93}$ Therefore, it seems likely that Ranrike was a later incorporation to the law area of Viken and that the law area originated in the inner, central parts of Viken (Figure 5.8). ${ }^{94}$

If Grenland belonged to Viken before the Viking Age and Ranrike did not, Lunde would have had a central location (Figure 5.8). It is unknown if there was a common law-thing in Viken before the Borgarthing, which must have come into being after the town of Borg was founded in the early 11 th century and became the legal and administrative centre for the whole area. Borg has a central location next

\footnotetext{
92 This is indicated by two things; one is that his predecessor, Simon the law man, around 1200 lived on the farm Tom in Råde skipreiða (S. Sturluson, Heimskringla, Sverres saga, chap. 162), and secondly, that he passed a sentence in Follo skipreiða (DN I, 3/1207-17), both in Vingulmork county (Indrebø, 'Spreidde merknader', 492).

93 Stylegar and Norseng, 'Del 2', pp. 379-97.

94 Ødegaard, 'Tingsted og territorium', pp. 98-9.
} 
to the border of Ranrike. The construction should therefore be seen in conjunction with Olaf II Haraldsson's attempt to seclude Ranrike and his disputes with the Danes over supremacy of Viken, as the saga also describes. ${ }^{95}$ The establishment of Borg as a common thing should thus be regarded as an attempt at royal regulation of the law provinces of Eastern Norway. ${ }^{96}$ Another part of this process was probably the erection of the fylki-churches with assemblies where royal officials (sg. ON sýslumaðr) became responsible for administration and law enforcement. ${ }^{97}$ It is likely that when the king tried to consolidate his power, it was important to take control of the thing organisation and legal matters in the districts.

At the beginning of the 11th century, King Olaf II Haraldsson moved the lawthing from Tjølling to Borg, near the border to Ranrike, as a way to strengthen the political and legal inclusion of the new law-parish. Bommestad's central location in South Vestfold sýsla might indicate functions serving that region. The document from Tjølling in 1557, however, testifies that the regional thing was held there, underlining the continued importance of the old thing and church site. It is possible, although uncertain, that after the law-thing was moved to Borg, the thing for Southern Vestfold was shifted from Bommestad to Tjølling.

\section{Conclusion}

Large cooking-pit sites have been interpreted as remains of recurrent large-scale gatherings, where political and legal business may have been important components. It is argued here that the cooking-pit sites at Lunde and Bommestad functioned as thing-sites in the early Iron Age. The Lunde and (chronologically later) Tjølling things may be the predecessors of the historical law-thing, the Borgarthing, established in the 11th century in the royal town of Borg as a way for the king to increase his control over the law province. While the thing may have been in origin communal in nature, during the state formation process in Norway beginning in the 9th century, the king increasingly took control over its organisation. As part of this process, thing-sites were moved and new administrative areas with royal officials were created. The process led to more formalised systems of governance and administration. The interpretation of at least some large cooking-pit sites as early thing-sites has major implications for the interpretation of social and political organisation in Scandinavia in the early centuries AD. It indicates advanced social fellowship and organisation, perhaps already even then related to administrative areas and fixed assembly sites. Over time, places for meetings and those which promoted social cohesion were of growing importance for the elites' claim to power and extension of control over the landscape.

95 St Olaf's saga, chs 54-61.

96 Ødegaard, 'Tingsted og territorium', pp. 105-6.

${ }^{97}$ J. Brendalsmo, 'Fylkeskirken i Hedrum', in O. Bjerke (ed.), Hedrum kirke. 950-årsjubileum 2010 (Hedrum, Hedrum kirke, 2010), pp. 27-35 at 31; Indrebø, 'Fylke og fylkesnamn', 36. 